\title{
Food-Biofuels Interactions: The Case of the U.S. Biofuels Market
}

\author{
Zuzana Kapustová, Jaroslav Kapusta, Peter Bielik
}

Faculty of Economics and Management, Slovak University of Agriculture in Nitra, Slovakia

\begin{abstract}
Corn refers to the main feedstock for U.S. biofuels production and together with soybean oil, as typical biofuel food commodity that can be converted into biodiesel, accounts for over 90 percent of biofuels production in the United States. The paper focuses on the nexus of agri-food and energy markets in U.S. and investigates the interrelationships between the biofuel prices and prices of soybean oil, corn and wheat. Co-integration analysis and vector error correction model are carried out in order to investigate the relationship between the price series. The results show that biofuels and food price levels are co-integrated in the long run. These links show that food prices increment with a rise in biofuels prices. Additionally, not only food prices are determined by biofuels prices, but also vice versa.
\end{abstract}

\section{Keywords}

Biodiesel, biofuel, co-integration, ethanol, price.

Kapustová, Z., Kapusta, J. and Bielik, P. (2018) "Food-Biofuels Interactions: The Case of the U.S. Biofuels Market", AGRIS on-line Papers in Economics and Informatics, Vol. 10, No. 4, pp. 27-38. ISSN 1804-1930. DOI 10.7160/aol.2018.100403.

\section{Introduction}

In recent years, the role of biofuel in the determination of high agricultural commodity prices has become one of the ongoing issues debated by energy, environmental and agricultural economists interested in the question of the sustainable development of biofuels (Bentivoglio and Rasetti, 2015). Later on, Bentivoglio et al. (2016) add that the issue of foodbiofuels interactions gained a new dimension and the research on price interdependencies between food, energy and biofuel markets has become a frequently debated topic since the food crisis.

Chakravorty et al. (2015) mention that biofuels have been blamed universally for past increases in world food prices, and many studies have shown that energy mandates in the United States and European Union may have a large $(30-60$ percent $)$ impact on food prices. Alexander and Hurt (2007) state that the primary impact of biofuels on food inflation is from increases in the farm prices of commodities that contribute to producing our food supply, like corn, soybean meal, soybean oil, wheat, barley, and oats. Condon et al. (2015) conduct a meta-analysis to identify the factors that drive the variation in crop price impacts and add that the baseline and policy ethanol volumes, projection year, inclusion of ethanol co-products, biofuel production from other feedstocks, and modelling framework explain much of the differences in price effects across studies and scenarios. Pfuderer and Castillo (2008) show how new biofuel demand will shift the food and feed demand curve outwards, resulting not only in higher feedstock output but also higher prices (Figure 1).

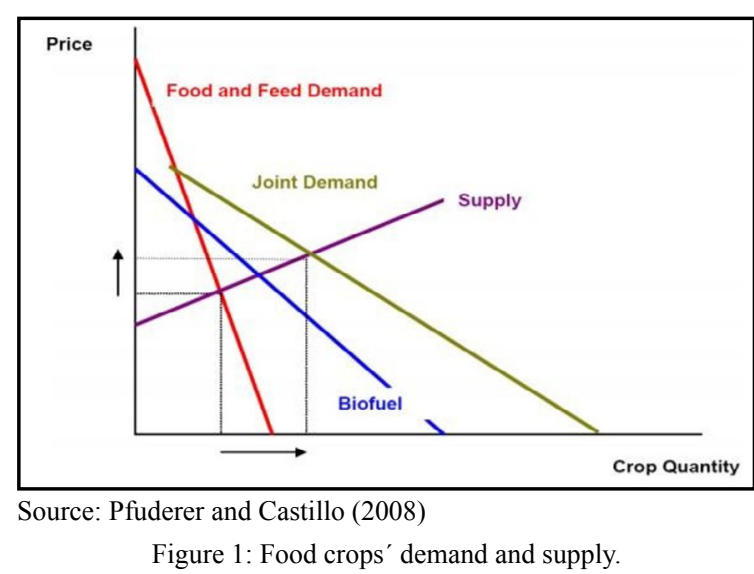

On the other hand, Baier et al. (2009) estimate that the increase in world biofuels production accounts for just over 12 percent of the rise in global food prices, with increased U.S. biofuel production accounting for roughly 60 percent of this total increase and conclude that nearly 90 percent of the price increase in global food prices is due 
to factors other than biofuels production. Flammini (2008) says that the persistent critique of biofuels' impact upon global food price increases depends upon a number of factors and not least natural constraints, markets and policies development and, importantly, upcoming pipeline technologies. Moreover, the different projections of the impact of biofuel production on food prices are difficult to resolve due to the specific assumptions underlying each model, the scope of the studies, their time horizon, the choices of different policy scenarios, or even more simply the definition of "food prices" and of aggregate commodity prices, as noted by Gerber et al. (2008). Also Ajanovic (2011) finds out that within the period $2000-2009$ the volatility of feedstocks prices has not been only the consequence of continuously increasing biofuels production, but the largest part of these volatilities was caused by other impact parameters such as oil price and speculation. Furthermore, Zilberman et al. (2013) demonstrate that biofuels have not been the most dominant contributor to the recent food-price inflation and different biofuels have different impacts. Hochman et al. (2012) show that although biofuel was an important contributor to the food-price inflation of 2001-2008, its effect on food-commodity prices declined after the recession of 2008/09. Kristoufek et al. (2012) show that ethanol is positively affected by corn and it causes changes in the US gasoline, but not vice-versa. Additionally, their results confirm that biodiesel is very strongly influenced by German diesel prices and also by soybeans prices. Other studies related to the U.S. evidence of biofuel and food price interactions are presented in Table 1.

\section{The biofuel market in U.S.: An overview}

As stated by Trujillo-Barrera et al. (2012), policy has played a crucial role in stimulating biofuel

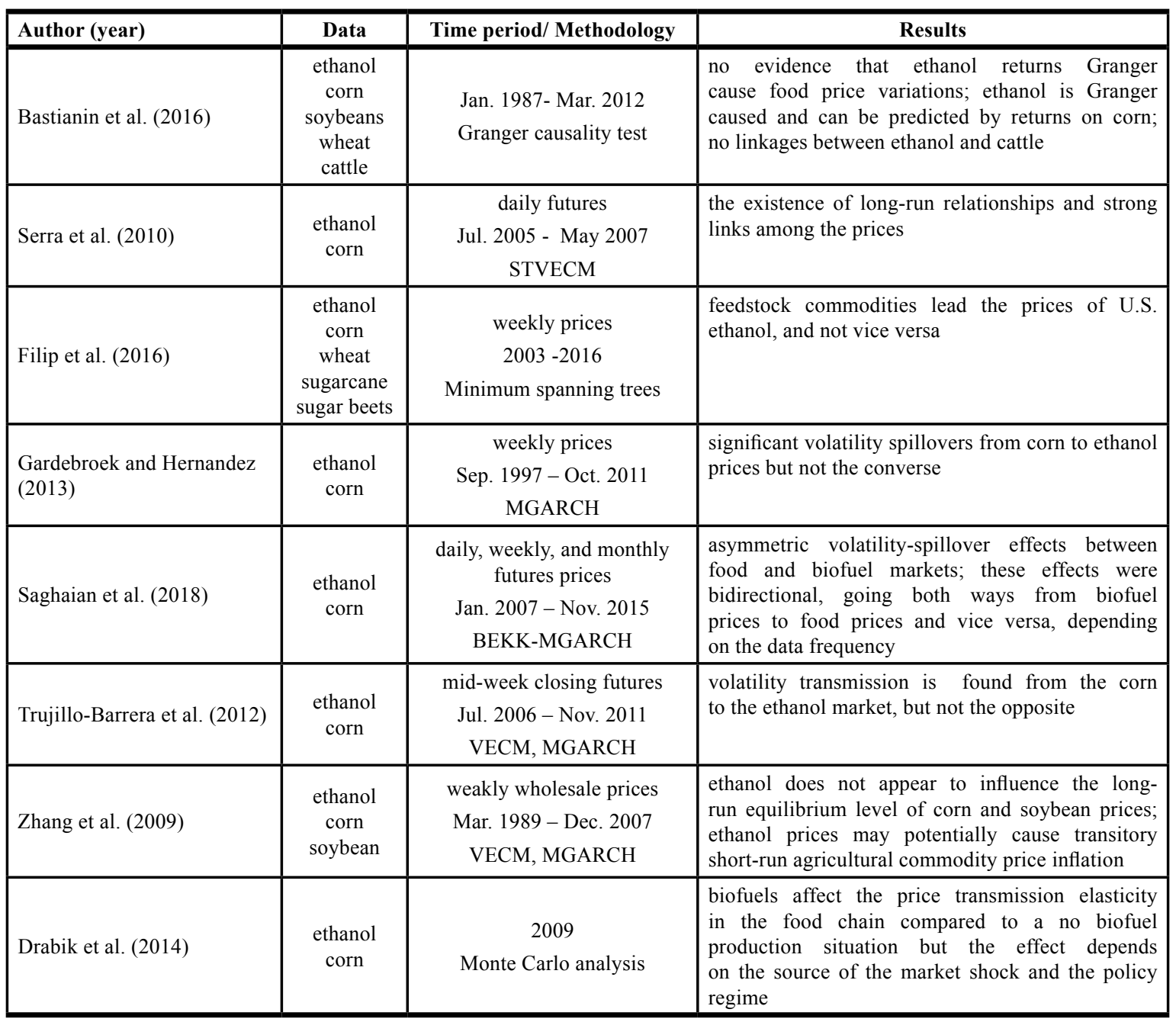

Source: authors' processing 
production growth. The Energy Policy Act of 2005 took the first noticeable step towards building the biofuel industry in the U.S. by requiring a specific amount of ethanol to be consumed as fuel, which was followed by the Energy Independence and Security Act of 2007 (EISA 2007) establishing the Renewable Fuel Standard (RFS) that set the apportioned mandated quantity for the different feedstock (Hochman et al., 2017). The Energy Independence and Security Act modified RFS1 and enacted the second and most recent RFS program, called RFS2, in order to differentiate among different types of renewable feedstock depending on whether it was cellulosic biofuel, biomass-based diesel, advanced biofuel, or renewable fuels (Adusumilli and Leidner, 2014). Additionally, RFS2 increases the mandated usage volumes and extends the time frame over which the volumes ramp up through at least 2022 (e.g. the mandate grows from a minimum of 9.0 billion gallons of total renewable fuels in 2008, to minimum volume of 36 billion gallons per year by 2022) (Schnepf and Yacobussi, 2013). The U.S. fiscal incentives and mandates are different from state to state and they are complemented by those at the federal level (Janda et al., 2012). U.S. Federal policy incentivizes biofuel production using three main instuments: (1) offering tax credits to biofuel blenders; (2) imposing import duty on fuel ethanol; and (3) offering direct payments to producers of non-corn biofuel feedstocks and to biofuel manufacturing facilities toward purchasing biomass (Adusumilli and Leidner, 2014). The Volumetric Ethanol Excise Tax Credit (VEETC), known as the "ethanol blenders' credit", was the major federal tax incentive that supports the use of ethanol and expired at the end of 2011 (Diggs, 2012). The tax credits included in VEECT were: (1) an import tariff of 0.54 USD per gallon aimed to offset the ethanol blending tax credit, so that only domestic ethanol producers would benefit from credit and to prevent large-scale direct import from Brazil; (2) a 0.45 USD per gallon credit of pure ethanol blended with gasoline to blenders of ethanol provided as an incentive to encourage ethanol use in gasoline after the renewal of the VEETC under the Farm Bill in 2008 (U.S. Energy Information Administration, 2012; Wu and Langpap, 2015; Monteiro et al., 2012). The biodiesel market remains much smaller than the market for ethanol, though its rate of growth has been faster (The federal biodiesel blender's tax credit, valued at $\$ 1$ per gallon, expired several times, most recently at the end of 2016 (U.S. Energy Information Administration, 2017).
The paper intends to contribute to the better understanding of the transmission of biofuel prices to food commodity prices by using time series econometric methods. The paper focuses on the nexus of agri-food and energy markets in U.S. with the aim to confirm or refute that biofuels are contributor to the food prices through the farm prices of commodities that contribute to producing the food supply as well as interrelationships between biofuel and agricultural prices are investigated. Another contribution of our paper is that our study is extended to the research not only focusing on ethanol - corn nexus, as many studies are dealing with, but also on the price relationship between ethanol -wheat and biodiesel - soybean oil. The paper is structured as follows: Section 2 (Materials and methods) presents the methodology approach, performed to estimate price relationships, as well as data needed for analysis are described. The empirical results are presented in Section 3 (Results and discussion) and conclusion is provided in Section 4.

\section{Materials and methods}

Corn, soybean oil and wheat refer to typical biofuel food commodities that can be (and have been) converted into biofuel and whose price links with biofuels (biodiesel, ethanol) are investigated in the paper. Monthly prices of ethanol (USD/ gallons), biodiesel (USD/gallons), corn (USD/ metric ton), soybean oil (USD/metric ton), wheat (USD/metric ton) are collected over the period January 2007 to February 2017. The food prices as well as prices of biofuels are extracted from United States Department of Agriculture (National Agricultural Statistics Service).

Time series model is an appropriate technique to study causal linkages between biofuels and food prices and to evaluate price level connections using co-integration analysis and Vector error correction model (VECM) (Bentivoglio, 2016; Hassouneh et al., 2011).

In order to avoid incorrect inference, as a result of failure to meet the assumption of stationarity, it is important to take properties of the data into account (Johansen, 2012). Hence, the stationarity of the time series is investigated. A time series is considered stationary, when its mean, variance and auto-covariance are not influenced by time; however, most economic time series have nonstationary characteristics because they exhibit trend, seasonality or other cyclical fluctuations (Katrakilidis et al., 2015). 
Non-stationarity means presence of unit roots, thus a variable contains a unit root if it is non-stationary (Kharin, 2018). Differencing the time series, that contains a unit root, is often used to render it stationary (Box and Jenkins, 1976). A procedure for testing non-stationarity based on the presence of a unit root was developed by Dickey and Fuller (1979). The augmented version of original DickeyFuller test (Dickey and Fuller, 1981) is one of the best known and most widely used approach to determine a unit root in a time series sample under the hypotheses H0: I (1) (presence of unit root - the series is nonstationary) versus H1: I (0) (absence of unit root - the series is stationary), and it allows testing of higher orders of autoregressive processes. The Augmented Dickey-Fuller (ADF) test is based on the following form:

$y_{t}=\mu+\beta t+\alpha y_{t-1}+\sum_{i=1}^{k} c_{i} y_{t-1}+\varepsilon_{t}$

where $\mu$ is the constant, $\beta$ is the coefficient on the time trend, $k$ is the lag order of the autoregressive process, $y_{t-i}$ is the lagged difference of $y$ whose magnitude is measured by $c$ and $\varepsilon$ is the error.

If the series of the variables are integrated of the same order, Johansen co-integration test is performed for finding the presence of a longterm relationship (co-integrating vector) between the selected time series (Kapusuzoglu and Karacaer Ulusoy, 2015). The analysis of cointegration and model based inference in the vector autoregressive framework was introduced by Johansen (1988). The evidence of co-integration between food and fuel price series means that two series (commodity price series) 'move together' over time towards equilibrium (Bracco, 2017; Bakhat and Würzburg, 2013). Johansen's method takes as a starting point the vector autoregression (VAR) of order $p$ given by:

$$
\mathrm{Y}_{\mathrm{t}}=\Pi_{1} \mathrm{Y}_{\mathrm{t}-1}+\Pi_{2} Y_{t-2}+\ldots+\Pi_{p} Y_{t-p}+u_{t}
$$

where $Y_{t}$ is an $\mathrm{n} \times 1$ vector of variables that are integrated of order one, that is, $\mathrm{I}(1), u_{t}$ is an $\mathrm{n} \times 1$ vector of innovations while $\Pi_{1}$ through $\Pi_{\mathrm{p}}$ are $\mathrm{m} \times \mathrm{m}$ coefficient matrices. Johansen (1991) defines two different test statistics for indicating the number of co-integrating relations: the Trace Test and the Maximum Eigenvalue Test. The Trace test is a joint test that tests the null hypothesis of no co-integration $\left(\mathrm{H}_{0}: \mathrm{r}=0\right)$ against the alternative hypothesis of co-integration $\left(\mathrm{H}_{1}: \quad \mathrm{r}>0\right)$. The Maximum Eigenvalue test conducts tests on each eigenvalue separately. It tests the null hypothesis that the number of co-integrating vectors is equal to $r$ against the alternative of $r+1$ co-integrating vectors.

However, co-integration does not reveal anything about the direction of causality (Avalos, 2014; Ciaian and Kancs, 2011). Thus, VECM is applied in order to evaluate the short run and long run properties of the cointegrated series (Obadi, 2014). The standard VECM is considered according to the following equation (Bentivoglio et al., 2016):

$$
\Delta Y_{t}=\Pi Y_{t-1}+\sum_{i=1}^{p-1} \Gamma_{i} \Delta Y_{t-i}+v+\varepsilon_{t}
$$

where $Y_{t}$ is an $\mathrm{m} \times 1$ vector of variables as in a VAR; $\Delta Y_{t}$ is an $\mathrm{m} \times 1$ vector of the first differences of the variables in $Y ; Y$ is an $\mathrm{m} \mathrm{x} 1$ vector of intercept coefficients; $\Pi$ and the $\Gamma_{\mathrm{i}}$ are $\mathrm{m} \times \mathrm{m}$ coefficient matrices; $\varepsilon_{t}$ is an $\mathrm{m} \times 1$ error vector with contemporaneous correlation, but no autocorrelation, like the error vector in a VAR. The $\Pi$ matrix can be decomposed as $\Pi=\alpha \beta$, with $\beta$, namely the cointegrating vector, describing a long run equilibrium and $\alpha$ gives the speed of adjustment with which prices return to the long run equilibrium (or error correction term ECT) (Cabrera and Schulz, 2013). A high absolute value for $\alpha$, indicates a high speed of price adjustment and a more efficient market (Growitsch et al., 2013). Since the prices are expressed in logarithms, the coefficient $\beta$ is the long-run elasticity. The long-run causality is tested by the significance of the speed of adjustment $(\alpha)$ in the equations (weak exogeneity test). Schreiber (2011) explains that weak exogeneity means that a variable is not (Granger-) caused by others in the long run. Once a number of variables are found to be cointegrated, then in the short run, deviations from this long-run equilibrium will feed back on the changes in the dependent variable in order to force the movement towards the longrun equilibrium (Bekhet, 2009).

\section{Results and discussion}

The econometric models, mentioned earlier, provide an alternative way to estimate the effect of biofuels price on food price. In the past decade, the prices of most agrarian commodities reached the historic maximum in 2007 - 2008. This situation, apart from climatic, production conditions was affected by the development of biofuel production (a decline in world cereal stocks), which has increased demand for cereals, oilseeds 
and sugar cane for non-food use and encouraged farmers to increase their offer on domestic and international markets. Prices of most agricultural commodities began to decline again as a result of the consolidation of world cereal stocks and the onset of the economic recession at the end of 2008. Food prices have moved in a close relationship with biofuels prices apart from 2012 and the first two-thirds of 2013 when drought sharply reduced supplies (see logarithmic transformations of prices from January 2007 to February 2017 in Figure 2). Furthermore, ethanol production experienced slowdown at the rates of prior years because of the saturation of the U.S. gasoline market with E10 coupled with less-favourable export markets during 2012 - 2013. Irwin and Good (2017) explain that biodiesel prices were pushed up substantially due to diesel blenders racing to take advantage of the $\$ 1$ per gallon biodiesel tax. The price of soybean oil could increase sharply in 2018 as a result of US anti-dumping action against vegetable oils for biodiesel produced by Argentina and Indonesia (Gyekye, 2017).The summary of descriptive statistics is shown in Table 2. In the next step the stationarity properties of the series will be discussed followed by the co-integration analysis.

The standard test proposed by Dickey and Fuller in its augmented form (ADF) is used in order to investigate the stationarity/non-stationarity properties of the selected price series. The ADF test tests the null hypothesis of a unit root process against the alternative of a stationary process. In our case, null hypothesis of ADF test is confirmed meaning that the level of price series has a unit root i.e. are integrated of order 1 . On the contrary, the ADF provides evidence of stationarity of the first differences of the time series (Table 3). All tests are carried out without constant or including either just a constant, or a constant and a trend in the test equation. The lags of the variables were determined by Akaike criterion, Schwartz

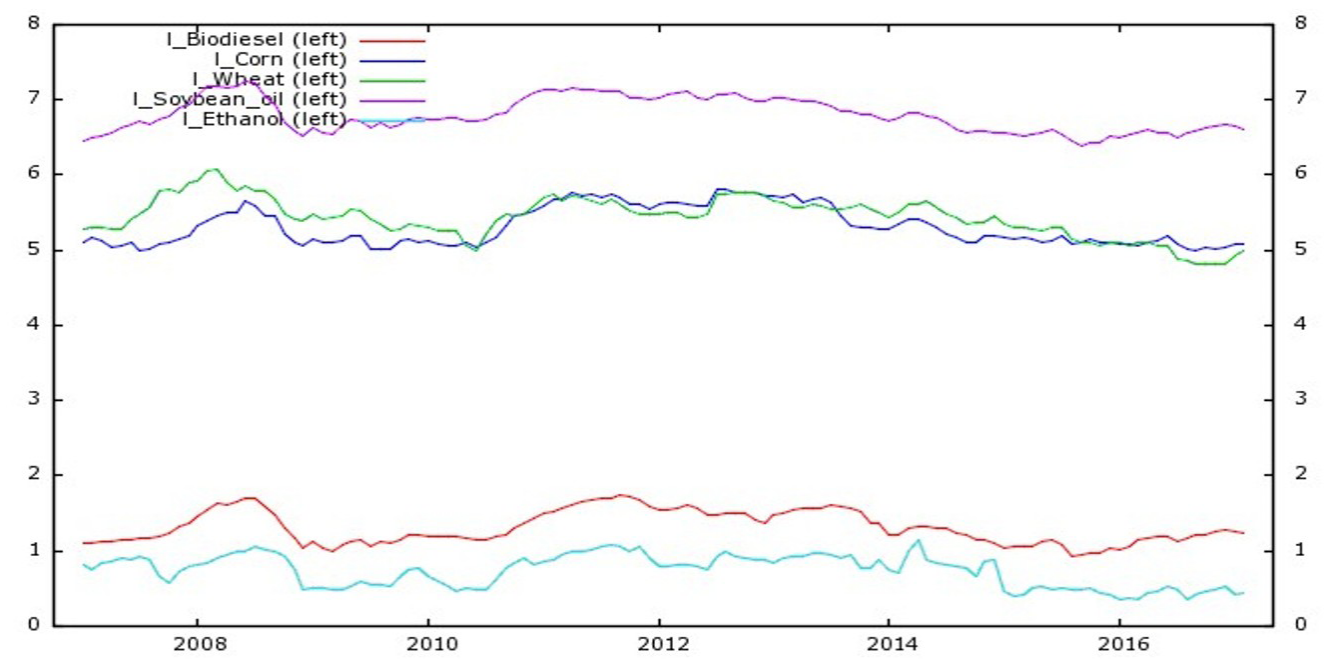

Source: authors' processing based on National Agricultural Statistics Service

Figure 2: Food and energy prices, January 2007 - February 2017 (logarithmic transformation).

\begin{tabular}{lccccc}
\hline & Ethanol & Biodiesel & Corn & Soybean oil & Wheat \\
\hline Mean & 2.14149 & 3.80746 & 210.092 & 920.295 & 238.76 \\
Median & 2.21000 & 3.44625 & 179.215 & 860.820 & 237.70 \\
Minimum & 1.42000 & 2.55000 & 147.130 & 590.250 & 122.51 \\
Maximum & 3.15000 & 5.74200 & 332.950 & 1414.42 & 439.72 \\
Std. Dev. & 0.441215 & 0.852418 & 57.2397 & 214.518 & 63.043 \\
C.V. & 0.206032 & 0.223881 & 0.272450 & 0.233097 & 0.26405 \\
Skewness & 0.00951078 & 0.727826 & 0.727826 & 0.478245 & 0.43755 \\
Ex. kurtosis & -1.19141 & -0.979234 & -0.979234 & -1.06046 & 0.28773 \\
\hline
\end{tabular}

Source: authors' processing 


\begin{tabular}{|c|c|c|c|c|}
\hline & & & ADF test & \\
\hline & Lag & without $\mathrm{C}$ & $\mathrm{C}$ & C\&T \\
\hline Ethanol & 1 & -0.765411 & -1.96732 & -2.22747 \\
\hline Biodiesel & 2 & -0.480151 & -2.58669 & -2.71352 \\
\hline Corn & 1 & -0.515662 & -1.69147 & -1.71287 \\
\hline Soybean oil & 2 & -0.516727 & -2.50135 & -2.96652 \\
\hline Wheat & 1 & -0.69215 & -2.11946 & -2.97522 \\
\hline d_ethanol & 1 & $-9.91265^{* * *}$ & $-9.885 * * *$ & $-9.85316^{* * *}$ \\
\hline d_biodiesel & 1 & $-5.38551 * * *$ & $-5.36234 * * *$ & $-5.36495 * * *$ \\
\hline d_corn & 1 & $-6.44123 * * *$ & $-6.41346 * * *$ & $-6.44047 * * *$ \\
\hline d_soybean oil & 1 & $-5.46871 * * *$ & $-5.44419 * * *$ & $-5.48522 * * *$ \\
\hline d_wheat & 1 & $-7.3663 * * *$ & $-7.33834 * * *$ & $-7.38793 * * *$ \\
\hline
\end{tabular}

Note: "C" and "C\&T" indicate whether a constant and a constant and a trend have been respectively included in the test equation; $* * *$ null hypothesis of non-stationarity rejected at $1 \%$ significance level

Source: authors' processing

Table 3: Augmented Dickey- Fuller test.

Bayesian criterion and Hannan-Quinn criterion.

Cointegration test could be used for testing long run relationship of the time series because of proving non-stationarity of the level of variables by the above stationarity test (ADF test). Co-integration is tested by Johansen trace test and L-max test, where the null hypotheses of no co-integration $(\mathrm{r}=0)$ are rejected at $5 \%$ significance level, whereas the null of $r=1$ cannot be rejected, thus the test gives an evidence for a long run relationship between the price series. The co-integration test confirms the presence of one co-integrating vector for the selected price pairs (Table 4).

The prices are transformed into natural logarithms for the estimations, since the long-run coefficients can then be interpreted as long-run price transmission elasticities (Busse and Ihle, 2009). The coefficients in the long-run relationship are long-run elasticities. Thus, 1 percent increase in biodiesel price leads to 1.16 percent increase in the price of soybean oil (Table 5). On the contrary, the co-integrating parameter is 1.77 for the corn-ethanol price pair, implying that 1 percent rise in price of ethanol will bring about, in the long run, a 1.77 percent increase in the price of corn. Co-integration vector has a following form in wheat-ethanol price pair: $(1.0000 ;-1.3609)$, meaning that an increase in price of ethanol by 1.00 percent results in a rise of wheat price by 1.36 percent. Adjustment coefficient $\alpha$ represents the error correction term. The adjustment parameter of the corn error correction model is statistically significant and corn prices adjust to a change in ethanol prices by 9.9 percent in one month. The estimated coefficient $\alpha$ of the ethanol error correction model is also positive and statistically significant, meaning that maize prices are determined by ethanol prices and vice versa, with a long run bidirectional causal effect which runs from one price to another. Similar findings are confirmed by Merkusheva and Rapsomanikis (2014) who consider corn as quasi-fixed input in the production of ethanol, and thus its price can influence the price of ethanol. Saghaian et al. (2018) also show that corn-ethanol links exist and corn and ethanol price volatility influence each other. Given a change in the corn price, ethanol prices respond to a change in corn prices fast and adjust to a change by 22 percent each month. The alfa parameter is statistically significant for both variables in case of wheat-ethanol system. About 17 percent of the disequilibrium is corrected within one month in case of wheat. The relationship between wheat and ethanol prices is simultaneous. According to Allen et al. (2017), price movements in agricultural commodities (corn, wheat) are related to the prices of ethanol and these linkages vary according to whether they are in low or high volatility regimes. The error correction coefficient of biodiesel is negative and significant at 5 percent level. Soybean oil prices as well as biodiesel prices adjust to their long-run path by 31 percent each month. The relationship for soybean oil-biodiesel price pair is also simultaneous, the biodiesel price drives that of soybean oil, but also vice versa. The empirical results of Carriquiry (2015) indicates that the price of soybean oil does not have a strong direct impact on the price of biodiesel in the short run, however, the study did not attempt to analyse whether the price of biodiesel affected that of soybean oil. On the other hand, Busse et al. (2010) found evidence for the influence in relation 


\begin{tabular}{lccc}
\hline & $\begin{array}{c}\text { Hypothesized no. } \\
\text { of co-integrating equation(s) }\end{array}$ & L-max test & Trace test \\
\hline \multirow{2}{*}{ Ethanol - Corn } & $\mathbf{r}=0^{* *}$ & 14.815 & 17.368 \\
& $\mathbf{r}=\mathbf{1}$ & $(0.0393)$ & $(0.0282)$ \\
& $\mathrm{2.5528}$ & $\mathbf{2 . 5 5 2 8}$ \\
& $\mathrm{r}=0^{* *}$ & $(0.5929)$ & $(0.5929)$ \\
\hline & & 13.78 & 14.162 \\
Ethanol - Wheat & $\mathbf{r}=\mathbf{1}$ & $(0.0302)$ & $(0.0234)$ \\
& & $\mathbf{0 . 3 8 2 1 1}$ & $\mathbf{0 . 3 8 2 1 1}$ \\
& $\mathrm{r}=0^{* *}$ & $(0.5993)$ & $(0.6076)$ \\
\hline \multirow{3}{*}{ Biodiesel - Soybean oil } & $\mathbf{r}=\mathbf{1}$ & 22.551 & 30.827 \\
& & $(0.0219)$ & $(0.0276)$ \\
& & $\mathbf{8 . 2 9 8 1}$ & $\mathbf{8 . 2 9 8 1}$ \\
& & $(0.2676)$ & $(0.2641)$ \\
\hline
\end{tabular}

Note: $* *$ denotes rejection of the hypothesis at $5 \%$ significance level; $p$-values are given in parentheses ()

Source: authors' processing

Table 4: Johansen cointegration test.

\begin{tabular}{|c|c|c|c|}
\hline & $\alpha$ adjustment coefficient & $\beta$ co-integrating vectors & Constant \\
\hline$\Delta$ soybean_oil & $0.312848^{*}$ & $\begin{array}{r}\text { 1_soybean_oil } \\
1.0000\end{array}$ & $-1.65360^{* *}$ \\
\hline$\Delta$ biodiesel & $-0.315790 * *$ & $\begin{array}{r}\text { 1_biodiesel } \\
-1.1640\end{array}$ & $1.67738 * *$ \\
\hline$\Delta$ corn & $0.0989273 * *$ & $\begin{array}{l}\text { 1_corn } \\
1.0000\end{array}$ & $-0.398943^{* *}$ \\
\hline$\Delta$ ethanol & $0.220637 * * *$ & $\begin{array}{l}\text { 1_ethanol } \\
-1.7725\end{array}$ & $-0.888609 * * *$ \\
\hline$\Delta$ wheat & $-0.171532 * * *$ & $\begin{array}{r}\text { 1_wheat } \\
1.0000\end{array}$ & $0.758232 * * *$ \\
\hline$\Delta$ ethanol & $0.100318^{*}$ & $\begin{array}{r}\text { 1_ethanol } \\
-1.3609\end{array}$ & $-0.448981 *$ \\
\hline
\end{tabular}

Note: $* * * / * * / *$ statistically significant at the $1 \% 5 \%$ and $10 \%$ levels

Source: authors' processing

Table 5: VECM

\begin{tabular}{lcccc}
\hline \multirow{2}{*}{ Equation } & \multicolumn{4}{c}{ Diagnostic test } \\
& Unadjusted R & Normality of residuals & ARCH test & Breusch -Godfrey test \\
\hline$\Delta$ soybean_oil & 0.73652 & \multirow{2}{*}{0.512156} & 0.964784 & 0.202463 \\
$\Delta$ biodiesel & 0.87755 & & 0.801994 & 0.195568 \\
$\Delta$ corn & 0.697842 & 0.569274 & 0.973204 & 0.344744 \\
$\Delta$ ethanol & 0.706623 & & 0.889009 & 0.124104 \\
$\Delta$ wheat & 0.323228 & 0.00208567 & 0.285868 & 0.205473 \\
$\Delta$ ethanol & 0.42279 & & 0.799891 & 0.217322 \\
\hline
\end{tabular}

Source: authors' processing

Table 6: VECM diagnostic checks.

between biodiesel and soybean oil in Germany, while the influence of soybean oil prices appears to be higher than that of biodiesel prices.

The diagnostic tests of VECM equations are computed in order to check autocorrelation (Breusch-Godfrey test), heteroscedasticity (ARCH test) and whether the residuals are normally distributed (Table 6). The models are considered as stable and reliable, do not include autocorrelation according to the Breusch-Godfrey test and the ARCH test indicates that the null hypothesis of homoscedasticity was accepted for all equations. 
The null hypothesis that the residuals are normally distributed is accepted for soybean oil - biodiesel and corn - ethanol equation.

\section{Conclusion}

The paper investigates price relationship in the food-biofuel nexus using time series modelling. Corn, soybean oil, wheat refer to typical biofuel food commodities that can be (and have been) converted into biofuel and whose price links with biofuels (biodiesel, ethanol) are investigated in the paper. The results of Johansen co-integration test provided an evidence for a long run relationship between feedstock and biofuels prices. Co-integrating parameters showed that implying rise in price of biofuels would bring, in the long run, an increase of the farm prices of the selected commodities that contribute to producing the food supply. Thus, biodiesel and ethanol have a positive impact on food prices. However, the results of weak exogeneity test also showed a long run bi-directional causal effect which runs from one price to another, indicating that not only the prices of biofuels drive food prices, but also vice versa. Furthermore, the speed of the reaction of corn, wheat prices upon the deviation of the system from the state of equilibrium is low in comparison to soybean oil prices that adjusted to their long-run path by 31 percent each month.

Our findings contribute to the current discussion about the biofuel-food nexus and brings new evidence on price interdependencies between food and biofuel markets that have become a frequently debated topic since the food crisis. Our findings are in line with Irwin (2013) who argues that ethanol prices have largely driven corn prices since the start of the ethanol boom. He adds that this does not mean that other factors have not also been important at times, such as weather, but, rather, that ethanol prices have consistently been the most important driver of corn prices at the margin since 2006. Zhang et al. (2009) also believe that fuel prices in general may potentially cause transitory short-run agricultural commodity price inflation. According to

Drabik et al. (2014) explain that the effect of biofuels on price transmission along the food chain depends also on the biofuel policy. It should be noted that Wisner (2014) also think that whether the corn-ethanol price relationship will be as close in the future as in the recent past will depend partly on whether the blend wall can be raised and domestic ethanol demand expands substantially in the years ahead. Therefore support system, aimed at the development of production and use of biofuels through standards that affect the proportion of bio-components in fuels used in a country, should not create an incentive to grow more e.g. corn as in case of U.S. Furthermore, the direct competition between food and biofuel, associated with the first generation of biofuels and their sustainability, could be solved by the increased development of secondgeneration biofuels produced from ligno-cellulosic feedstocks.

\section{Acknowledgements}

This work was supported by Grant Agency SUA in Nitra under project no. 04-GA SPU-16 and by the AgroBioTech Research Centre that was built in accordance with the project Building an 'AgroBioTech' Research Centre, ITMS 26220220180.

\section{Corresponding authors:}

Ing. Zuzana Kapustová, PhD.

Department of Economics, Faculty of Economics and Management

Slovak University of Agriculture in Nitra, Tr. A Hlinku 2, 94976 Nitra, Slovakia

E-mail: zuzana.lajdova@gmail.com

\section{References}

[1] Adusumilli, N. and Leidner, A. (2014) "The U.S. Biofuel Policy: Review of Economic and Environmental Implications", American Journal of Environmental Protection, Vol. 2, No. 4, pp. 64-70. ISSN 2328-7233. DOI 10.12691/env-2-4-1.

[2] Ajanovic, A. (2011) "Biofuels versus food production: Does biofuels production increase food prices?”, Energy, Vol. 36, No. 4, pp. 2070-2076. ISSN 0360-5442. DOI 10.1016/j.energy.2010.05.019. 
[3] Allen, D. E., Chang, C., McAleer, M. and Singh, A. K. (2017) "A cointegration analysis of agricultural, energy and bio-fuel spot, and futures prices", Applied Economics, Vol. 50, No. 7, pp. 804-823. ISSN 0003-6846. DOI 10.1080/00036846.2017.1340581.

[4] Alexander, C. and Hurt, Ch. (2007) "Biofuels and Their Impact on Food Prices", BioEnergy, ID-346-W, Department of Agricultural Economics, Purdue University, West Lafayette, IN, USA. [Online]. Available: https://www.extension.purdue.edu/extmedia/id/id-346-w.pdf [Accessed: 22 April 2018].

[5] Avalos, F. (2014) "Do oil prices drive food prices? The tale of a structural break", Journal of International Money and Finance, Vol. 42, pp. 253-271. ISSN 0261-5606. DOI 10.1016/j.jimonfin.2013.08.014.

[6] Baier, S., Clements, M., Griffiths, C. W. and Ihrig, J. E. (2009) "Biofuels impact on crop and food prices: Using an interactive spreadsheet", FRB International Finance Discussion Paper 967, Board of Governors of the Federal Reserve System. [Online]. Available: https://www.federalreserve.gov/ pubs/ifdp/2009/967/ifdp967.pdf [Accessed: 10 March 2018].

[7] Bakhat, M. and Wurzburg, K. (2013) "Price relationships of crude oil and food commodities", Economics for energy, Working Paper No. FA06/2013. [Online]. Available: http://www.eforenergy. org/docpublicaciones/documentos-de-trabajo/WPFA06-2013.pdf [Accessed: 20 March 2018].

[8] Bastianin, A., Galeotti, M. and Manera, M. (2016) "Ethanol and field crops: Is there a price connection?", Food Policy, Vol. 63, pp. 53-61. ISSN 0306-9192. DOI 10.1016/j.foodpol.2016.06.010.

[9] Bekhet, H. A. and Yusop, N. Y. M. (2009) "Assessing the Relationship between Oil Prices, Energy Consumption and Macroeconomic Performance in Malaysia: Co-integration and Vector Error Correction Model (VECM) Approach“, International Business Research, Vol. 2, No. 3, pp. 152-175. ISSN 1913-9012. DOI 10.5539/ibr.v2n3p152.

[10] Bentivoglio, D. and Rasetti, M. (2015) "Biofuel sustainability: review of implications for land use and food price", Rivista di Economia Agraria, Vol. LXX, No. 1, pp. 7-31. ISSN 0035-6190. DOI 10.13128/REA-16975.

[11] Bentivoglio, D., Finco, A. and Bacchi, M. R. P. (2016) "Interdependencies between Biofuel, Fuel and Food Prices: The Case of the Brazilian Ethanol Market", Energies, Vol. 9, No. 6, pp. 464. ISSN 1996-1073. DOI 10.3390/en9060464.

[12] Box, G. E. P. and Jenkins, G. M. (1976) "Time series analysis: Forecasting and control", Holden Day, San Francisco, 575 p. ISBN 978-0-816-21104-3.

[13] Bracco, S. (2017) "The Economics of Biofuels: The impact of EU bioenergy policy on agricultural markets and land grabbing in Africa", Abingdon, Oxon, NY: Routledge, $165 \mathrm{p}$. ISBN 978-1-138-65785-4.

[14] Busse, S. and Ihle, R. (2009) "German Rapeseed Oil and Biodiesel Pricing under Changing Market Conditions: A Markov-switching Vector Error Correction Model Approach", contributed paper prepared for presentation at the International Association of Agricultural Economists Conference, Beijing, China, August 16-22. [Online]. Available: http://ageconsearch.umn.edu/bitstream/51032/2/ Busse_173.pdf [Accessed: 15 March 2018].

[15] Busse, S., Brümmer, B. and Ihle, R. (2010) "The Pattern of Integration between Fossil Fuel and Vegetable Oil Markets: The Case of Biodiesel in Germany", Selected Paper prepared for presentation at the Agricultural \& Applied Economics Association 2010. AAEA, CAES, \& WAEA Joint Annual Meeting, Denver, Colorado, July 25-27. [Online]. Available: https://ageconsearch.umn. edu/bitstream/61010/2/Busse_AAEA.pdf [Accessed: 10 March 2018].

[16] Ciaian, P. and Kancs, A. (2011) "Interdependencies in the energy-bioenergy-food price systems: a cointegration analysis", Resource and Energy Economics, Vol. 33, No. 1, pp. 326-348. ISSN 0928-7655. DOI 10.1016/j.reseneeco.2010.07.004.

[17] Cabrera, L. B. and Schulz, F. (2013) "Volatility linkages between energy and agricultural commodity prices”, SFB 649: Ökonomisches Risiko, No. 2013-042. ISSN 1860-5664. DOI 10.18452/4482. 
[18] Carriquiry, M. A. (2015) "An examination of the relationship between biodiesel and soybean oil prices using an asset pricing model", Documentos de Trabajo (working papers) 15-17, Instituto de Economía - IECON. ISSN 1510-9305.

[19] Chakravorty, U., Hubert, M. H., Moreaux, M. and Nøstbakken, L. (2015) "The Long-Run Impact of Biofuels on Food Prices", Discussion paper. [Online]. Available: http://www.indiaenvironmentportal.org.in/files/file/The\%20LongRun\%20Impact\%20of\%20 Biofuels\%20on\%20Food\%20Prices.pdf [Accessed: 2 May 2018].

[20] Condon, N., Klemick, H. and Wolverton, A. (2015) "Impacts of Ethanol Policy on Corn Prices: A Review and Meta-Analysis of Recent Evidence", Food Policy, Vol. 51, pp. 63-73. ISSN 0306-9192. DOI 10.1016/j.foodpol.2014.12.007.

[21] Dickey, D. and Fuller, W. A. (1979) "Distribution of the estimators for autoregressive time series with a unit root", Journal of the American Statistical Association, Vol. 74, pp. 427-431. ISSN 1537-274X. DOI 10.1080/01621459.1979.10482531.

[22] Dickey, D. and Fuller, W. A. (1981) "Likelihood ratio statistics for autoregressive time series with a unit root", Econometrica, Vol. 49, No. 4, pp. 1057-72. ISSN 1468-0262. DOI 10.2307/1912517.

[23] Diggs, A. (2012) "The Expiration of the Ethanol Tax Credit: An Analysis of Costs and Benefits", Policy Perspectives, Vol. 19, pp. 47-58. ISSN 1085-7087. DOI 10.4079/pp.v19i0.10425.

[24] Drabik, D., Ciaian, P. and Pokrivcak, J. (2014) "Biofuels and Vertical Price Transmission: The Case of the U.S. Corn, Ethanol, and Food Markets", 2014 International Congress, August 2629, 2014, Ljubljana, Slovenia 182697, European Association of Agricultural Economists. [Online]. Available: https://ageconsearch.umn.edu/bitstream/182697/2/Drabik-Biofuels_and_vertical_price_ transmission-512_a.pdf [Accessed: 15 June 2018].

[25] Filip, O., Janda, K., Kristoufek, L. and Zilberman, D. (2016) "Foods, Fuels or Finances: Which Prices Matter for Biofuels?" CAMA Working Paper No. 63/2016. [Online]. Available: http://www.cireqmontreal.com/wp-content/uploads/2017/01/janda.pdf [Accessed: 10 May 2018].

[26] Flammini, A. (2008) "Biofuels and the underlying causes of high food prices", Food and Agriculture Organisation, Rome. [Online]. Available: http://www.globalbioenergy.org/fileadmin/user_upload/ gbep/docs/BIOENERGY_INFO/0810_Flammini_-_Biofuels_and_the_underlying_causes_of_ high_food_prices_GBEP-FAO.pdf [Accessed: 23 April 2018].

[27] Gardebroek, C. and Hernandez, M. A. (2013) "Do energy prices stimulate food price volatility? Examining volatility transmission between US oil, ethanol and corn markets", Energy Economics, Vol. 40, pp. 119-129. ISSN 0140-9883. DOI 10.1016/j.eneco.2013.06.013.

[28] Gyekye, L. (2017) "Soybean oil price set to rise in 2018 due to US biodiesel anti-dumping policy", Biofuels International. [Online]. Available: https://biofuels-news.com/display_news/12408/ soybean_oil_price_set_to_rise_in_2018_due_to_us_biodiesel_antidumping_policy/ [Accessed: 5 May 2018].

[29] Gerber, N., van Eckert, M. and Breuer, T. (2008) “The Impacts of Biofuel Production on Food Prices: a review", ZEF - Discussion Papers on Development Policy No. 127, Center for Development Research, Bonn. [Online]. Available: https://papers.ssrn.com/sol3/papers.cfm?abstract_id=1402643 [Accessed: 2 May 2018].

[30] Growitsch, C., Stronzik, M. and Nepal, R. (2013) "Price Convergence and Information Efficiency in German Natural Gas Markets", German Economic Review, Verein für Socialpolitik, Vol. 16, pp. 87-103. ISSN 1468-0475.

[31] Hassouneh, I., Serra, T. and Gil, J. M. (2011) "Non-Parametric and Parametric Modeling of Biodiesel - Sunflower Oil - Crude Oil Price Relationships", Paper presented at the EAAE 2011 Congress, Change and Uncertainty Challenges for Agriculture, Food and Natural Resources, August 30-September 2, Zurich. [Online]. Available: https://ageconsearch.umn.edu/bitstream/114554/2/ Hassouneh_Islam_122.pdf [Accessed: 12 May 2018]. 
[32] Hochman, G., Kaplan, S., Rajagopal, D. and Zilberman, D. (2012) "Biofuel and Food Commodity Prices", Agriculture, Vol. 2, pp. 272 - 281. ISSN 2077-0472. DOI 10.3390/agriculture2030272.

[33] Hochman, G., Traux, M. and Zilberman, D. (2017) "US Biofuel Policies and Markets", In Khanna M. a Zilberman D. (Eds.), Handbook of Bioenergy Economics and Policy: Vol. II, Modelling Land Use and Greenhouse Gas Implications, Natural Resource Management and Policy, Springer International Publishing AG 2017. ISBN 978-1-4939-6904-3. DOI 10.1007/978-1-4939-6906-7_2.

[34] Irwin, S. (2013) "Ethanol Prices Drive Corn Prices, Right?", Department of Agricultural and Consumer Economics, University of Illinois. [Online]. Available: http://farmdocdaily.illinois. edu/2013/10/ethanol-prices-drive-corn-prices.html [Accessed: 23 April 2018].

[35] Irwin, S. and Good, D. (2017) "The Relationship between Biodiesel and Soybean Oil Prices", farmdoc daily, Vol. 7, p. 164. Department of Agricultural and Consumer Economics, University of Illinois at Urbana-Champaign. [Online]. Available: https://farmdocdaily.illinois.edu/wp-content/ uploads/2017/09/fdd070917.pdf [Accessed: 25 May 2018].

[36] Janda, K., Kristoufek, L. and Zilberman, D. (2012) "Biofuels: policies and impacts", Agric. Econ. Czech, Vol. 58, pp. 372-386. ISSN 0139-570X.

[37] Johansen, S. (1988) "Statistical analysis of cointegration vectors", Journal of Eco-nomic Dynamics and Control, Vol. 12, pp. 231-254. ISSN 0165-1889. DOI 10.1016/0165-1889(88)90041-3.

[38] Johansen, S. (1991) "Estimation and Hypothesis Testing of Cointegration Vectors in Gaussian Vector Autoregressive Models", Econometrica, Vol. 59, No. 6, pp. 1551-1580. ISSN 0012-9682. DOI $10.2307 / 2938278$.

[39] Johansen, S. (2012) "The analysis of nonstationary time series using regression, correlation and cointegration", Contemporary Economics, Vol. 6, No. 2, pp. 40-57. ISSN 2300-8814. DOI 10.5709/ce.1897-9254.39.

[40] Kapusuzoglu, A. and Karacaer, M. (2015) "The interactions between agricultural commodity and oil prices: an empirical analysis", Agric. Econ. - Czech, Vol. 61, No. 9, pp. 410-421. ISSN 0139-570X.

[41] Katrakilidis, C., Sidiropoulos, M. and Tabakis, N. (2015) "An Empirical Investigation of the Price Linkages between Oil, Biofuels and Selected Agricultural Commodities", Procedia Economics and Finance, Vol. 33, pp. 313-320. ISSN 2212-5671. DOI 10.1016/S2212-5671(15)01715-3.

[42] Kharin, S. (2018) "Price Transmission Analysis: the Case of Milk Products in Russia", AGRIS on-line Papers in Economics and Informatics, Vol. 10, No. 1, pp. 15-23. ISSN 1804-1930. DOI 10.7160/aol.2018.100102.

[43] Kristoufek, L., Janda, K. and Zilberman, D. (2012) "Mutual Responsiveness of Biofuels, Fuels and Food Prices", CAMA Working Paper 38/2012. Centre for Applied Macroeconomic Analysis, Australian National University, Canberra. [Online]. Available: https://cama.crawford.anu.edu.au/ pdf/working-papers/2012/382012.pdf [Accessed: 12 April 2018].

[44] Merkusheva, N. and Rapsomanikis, G. (2014) "Nonlinear cointegration in the foodethanol-oil system: Evidence from smooth threshold vector error correction models", ESA Working Paper No. 14-01, Agricultural Development Economics Division, Food and Agriculture Organization of the United Nations. [Online]. Available: http://www.fao.org/3/ai3697e.pdf [Accessed: 25 March 2018].

[45] Monteiro, N., Altman, I. and Lahiri, S. (2012) "The impact of ethanol production on food prices: The role of interplay between the U.S. and Brazil", Energy Policy, Vol. 41. pp. 193-199. ISSN 0301-4215. DOI 10.1016/j.enpol.2011.10.035.

[46] Obadi, M. (2014) "Are Food Prices Affected by Crude Oil Price: Causality Investigation”, Review of Integrative Business Economics Research, Vol. 3, No. 1, pp. 411-427. ISSN 2304-1013. DOI 10.13140/2.1.2822.2407.

[47] Pfuderer, S. and Castillo, M. (2008) "The Impact of Biofuels on Commodity Prices", UK Department for Environment, Food and Rural Affairs (DEFRA). [Online]. Available: http://sugarcane.org/ resourcelibrary/studies/The $\% 20$ Impact $\% 20$ of $\% 20$ Biofuels $\% 20$ on $\% 20$ Commodity $\% 20$ Prices.pdf [Accessed: 24 April 2018]. 
[48] Saghaian, S., Nemati, M., Walters, C. and Chen, B. (2018) “Asymmetric Price Volatility Transmission between U.S. Biofuel, Corn, and Oil Markets", Journal of Agricultural and Resource Economics, Vol. 43, No. 1, pp. 46-60. ISSN 1068-5502.

[49] Schnepf, R. and Yacobucci, B. D. (2013) "Renewable Fuel Standard (RFS): Overview and Issues", Congressional Research Service. Washington, DC. [Online]. Available: https://fas.org/sgp/crs/misc/ R40155.pdf [Accessed: 2 May 2018].

[50] Schreiber, S. (2011) "Estimating the natural rate of unemployment in euro-area countries with co-integrated systems", Applied Economics, Vol. 44, No. 10, pp. 1315-1335. ISSN 1466-4283. DOI 10.1080/00036846.2010.539548.

[51] Serra, T., Zilberman, D., Gil, J. M. and Goodwin B. K. (2010) "Nonlinearities in the U.S. corn-ethanol-oil-gasoline price system", Agricultural Economics, Vol. 42, No. 1, pp. 35-45. ISSN 1574-0862. DOI 10.1111/j.1574-0862.2010.00464.x.

[52] Trujillo-Barrera, A., Mallory, M. and Garcia, P. (2012) "Volatility Spillovers in U.S. Crude Oil, Ethanol, and Corn Futures Markets", Journal of Agricultural and Resource Economics, Vol. 37, No. 2, pp. 247-262. ISSN 1068-5502.

[53] U.S. Energy Information Administration (2012) "Biofuels Issues and Trends", U.S. Department of Energy Washington. [Online]. Available: https://www.eia.gov/biofuels/issuestrends/pdf/bit.pdf [Accessed: 20 March 2018].

[54] U.S. Energy Information Administration (2017) "U.S. biodiesel production still increasing despite expiration of tax credit", [Online]. Available: https://www.eia.gov/todayinenergy/detail. php?id=34152 [Accessed 18 March 2018].

[55] United States Department of Agriculture (2018) National Agricultural Statistics Service. [Online]. Available: https://www.nass.usda.gov/Publications/Ag_Statistics/ [Accessed 12 March 2018].

[56] Wisner, R. (2014) "Ethanol, Gasoline, Crude Oil and Corn Prices: Are the Relationships Changing?" AgMRC Renewable Energy \& Climate Change Newsletter. [Online]. Available: https://www.agmrc. org/renewable-energy/ethanol/ethanol-gasoline-crude-oil-and-corn-prices-are-the-relationshipschanging/ [Accessed: 8 May 2018].

[57] Wu, J. J. and Langpap, C. (2015) "The Price and Welfare Effects of Biofuel Mandates and Subsidies", Environmental \& Resource Economics, Vol. 62, No. 1, pp. 35-57. ISSN 0924-6460. DOI 10.1007/s10640-014-9814-8.

[58] Zhang, Z., Lohr, L., Escalante, C. and Wetzstein, M. (2009) "Ethanol, Corn, and Soybean Price Relations in a Volatile Vehicle-Fuels Market", Energies, Vol. 2, pp. 320-339. ISSN 1996-1073. DOI 10.3390/en20200320.

[59] Zilberman, D., Hochman, G., Rajagopal, D., Sexton, S. and Timilsina, G. (2013) "The Impact of Biofuels on Commodity Food Prices: Assessment of Findings", American Journal of Agricultural Economics, Vol. 95, No. 2, pp. 275 - 281. ISSN 0002-9092. DOI 10.1093/ajae/aas037. 